\title{
On the validity of "Candidatus Dirofilaria hongkongensis" and on the use of the provisional status Candidatus in zoological nomenclature
}

\author{
Filipe Dantas-Torres ${ }^{1 *}$ (D) and Domenico Otranto ${ }^{2,3}$
}

\begin{abstract}
The fast development of molecular taxonomy is impacting our knowledge of the world parasite diversity at an unprecedented level. A number of operational taxonomic units have been uncovered and new species described. However, it is not always that new parasite species are being described in compliance with the International Code of Zoological Nomenclature. This is the case of "Candidatus Dirofilaria hongkongensis", a nematode found in dogs, jackals and humans in Hong Kong and parts of India. This name has been proposed without a formal description and without the designation of a holotype, and therefore is an unavailable name. Finally, we argue that using the provisional status Candidatus in zoological nomenclature is inappropriate, considering this term is not considered in the International Code of Zoological Nomenclature.
\end{abstract}

Keywords: Dirofilaria, Phylogeny, Taxonomy, New species, Nomenclature, Rules

\section{Letter to the editor}

Dirofilaria immitis and Dirofilaria repens are widespread nematodes of major medical and veterinary importance. Dirofilaria immitis is ubiquitous in distribution and $D$. repens is present in the Old World $[1,2]$. They are transmitted to animals and humans via the bite of infected female mosquitoes belonging to numerous species around the world [1].

In 2012, To et al. [3] reported three human cases of dirofilariosis in Hong Kong. One patient presented with cervical lymphadenopathy, one with an abdominal subcutaneous mass, and the other with a subconjunctival nodule. Cytochrome $c$ oxidase subunit 1 (cox1) gene sequences obtained from the three human patients were identical. Further analysis showed homologies of $96.2 \%$

*Correspondence: filipe.dantas@cpqam.fiocruz.br

${ }^{1}$ Department of Immunology, Aggeu Magalhães Institute, Oswaldo Cruz Foundation (Fiocruz), Recife, Brazil

Full list of author information is available at the end of the article and $89.3 \%$ to the cox 1 gene of $D$. repens and D. immitis, respectively. In a similar manner, a sequence of the 18S-ITS1-5.8S gene cluster was obtained from an intact worm, showing homologies of $94.0 \%$ and $94.9 \%$ to those of $D$. repens and D. immitis, respectively. To et al. [3] investigated the presence of this Dirofilaria sp. in dogs and cats, detecting $3 \%(6 / 200)$ of positive dogs and no positive cat. Finally, the cox 1 gene and 18S-ITS1-5.8S gene cluster obtained from dogs were found to be identical to those detected in the human patients. With solid evidence, To et al. [3] elegantly demonstrated that a new zoonotic species of the genus Dirofilaria, related to $D$. repens, was circulating among dogs and humans in Hong Kong, proposing the name "Candidatus Dirofilaria hongkongensis".

Subsequently, this parasite has been referred to as Dirofilaria hongkongensis, Candidatus Dirofilaria hongkongensis, Dirofilaria sp. hongkongensis, Dirofilaria sp. "hongkongensis", and Candidatus Dirofilaria (Nochtiella) Honkongensis, by different authors [3-15]. 
Unfortunately, To et al. [3] in the original reference to "Candidatus Dirofilaria hongkongensis" failed to identify either a holotype or give an appropriate morphological description, which are part of the rules of the International Code of Zoological Nomenclature (ICZN) [16]. Therefore, Dirofilaria hongkongensis must be considered nomen nudum and an unavailable name. This species name is not currently registered in ZooBank (as of 3 June 2020).

The parasite reported by To et al. [3] as "Candidatus Dirofilaria hongkongensis" has been detected in an Austrian traveller returning from the Indian subcontinent [9], in dogs, jackals and humans in south India [12, 13], and again in a human in Hong Kong [5, 15]. Other authors identified additional genotypes related to $D$. repens, referred to as Candidatus Dirofilaria sp. 'Thailand II' (also referred to as Dirofilaria sp. 'Thailand II') and Dirofilaria sp. "Thailand III" - in cats in Thailand $[10,11]$. These genotypes were related but different from each other and different from "Candidatus Dirofilaria hongkongensis".

Different genotypes related to $D$. repens or to $D$. immitis have been reported in the Americas [1]. For instance, a nematode extracted from the eye of a human patient in Pará State (northern Brazil), morphologically similar to, but genetically distinct from $D$. immitis (percentage of nucleotide difference $5 \%$ and $6 \%$ for $12 S$ rDNA and cox 1 , respectively) [17]. Such a high nucleotide variation suggested the existence of a cryptic species of $D$. immitis in Brazil or of a closely related species. Nonetheless, in the absence of more data (e.g. additional male and female specimens, but also microfilariae from a proper host), no new species name was proposed.

Incidentally, other authors have also been using the provisional status Candidatus in zoological nomenclature (e.g. Candidatus Babesia vesperuginis and Candidatus "Theileria senegalensis") in recent years (e.g. $[18,19])$. This category has been proposed by Murray \& Schleifer [20] for recording the properties of putative taxa of prokaryotes and has been implemented by the International Committee on Systematics of Prokaryotes [21]. According to the International Code of Nomenclature of Prokaryotes (ICNP) [22], the provisional status Candidatus may be used to record the properties of putative taxa of prokaryotes and should be used for describing prokaryotic entities for which more than a mere nucleic acid sequence is available but for which characteristics required for description according to the ICNP are lacking. Furthermore, the ICNP provides a list of information that should be included in the description of a Candidatus: "(a) Genomic information, i.e. nucleic acid sequences apt to determine the phylogenetic position of the organism. (b) All information so far available on (c) structure and morphology (appropriate illustration) (d) physiology and metabolism (e) reproductive features (f) the natural environment, in which the organism can be identified by in situ hybridization or similar techniques for cell identification. (g) Any other available and suitable information" [22].

On the other hand, the provisional status Candidatus is not considered in the ICZN, which makes no reference regarding the use of this or similar term [16]. Therefore, the current use of this term in zoological nomenclature should be avoided, so as to avoid that several newly proposed names become unavailable. As emphasized elsewhere, the use of informal clade names is necessary until formal valid descriptions are available [23].

\section{Authors' contributions}

FDT performed the literature review and wrote the manuscript. DO reviewed the manuscript. Both authors read and approved the final manuscript.

\section{Funding}

FDT is the recipient of a research fellowship from the Conselho Nacional de Desenvolvimento Científico e Tecnológico CNPq (CNPq; 313118/2018-3).

Availability of data and materials

Not applicable.

Ethics approval and consent to participate

Not applicable.

Consent for publication

Not applicable.

\section{Competing interests}

The authors declare that they have no competing interests.

\section{Author details}

${ }^{1}$ Department of Immunology, Aggeu Magalhães Institute, Oswaldo Cruz Foundation (Fiocruz), Recife, Brazil. ${ }^{2}$ Department of Veterinary Medicine, Università degli Studi di Bari, Valenzano, Bari, Italy. ${ }^{3}$ Faculty of Veterinary Sciences, Bu-Ali Sina University, Hamedan, Iran.

Received: 30 April 2020 Accepted: 30 May 2020

Published online: 05 June 2020

References

1. Dantas-Torres F, Otranto D. Overview on Dirofilaria immitis in the Americas, with notes on other filarial worms infecting dogs. Vet Parasitol. 2020;282:109113.

2. Genchi C, Kramer LH. The prevalence of Dirofilaria immitis and D. repens in the Old World. Vet Parasitol. 2020;280:108995.

3. To KK, Wong SS, Poon RW, Trendell-Smith NJ, Ngan AH, Lam JW, et al. A novel Dirofilaria species causing human and canine infections in Hong Kong. J Clin Microbiol. 2012;50:3534-41.

4. Suzuki J, Kobayashi S, Okata U, Matsuzaki H, Mori M, Chen KR, et al. Molecular analysis of Dirofilaria repens removed from a subcutaneous nodule in a Japanese woman after a tour to Europe. Parasite. 2015;22:2.

5. Kwok RP, Chow PP, Lam JK, Fok AC, Jhanji V, Wong VW, et al. Human ocular dirofilariasis in Hong Kong. Optom Vis Sci. 2016;93:545-8.

6. Liesner JM, Krücken J, Schaper R, Pachnicke S, Kohn B, Müller E, et al. Vector-borne pathogens in dogs and red foxes from the federal state of Brandenburg, Germany. Vet Parasitol. 2016;224:44-51.

7. Rakova VM. Dirofilariasis: current aspects of studies. Med Parazitol (Moscow). 2016;4:48-52 
8. Nazar N, Lakshmanan B, Jayavardhanan KK. Molecular characterization of human Dirofilaria isolates from Kerala. Indian J Med Res. 2017;146:528-33.

9. Winkler S, Pollreisz A, Georgopoulos M, Bagò-Horvath Z, Auer H, To KK, et al. Candidatus Dirofilaria hongkongensis as causative agent of human ocular filariosis after travel to India. Emerg Infect Dis. 2017;23:1428-31.

10. Yilmaz E, Fritzenwanker M, Pantchev N, Lendner M, Wongkamchai S, Otranto D, et al. The mitochondrial genomes of the zoonotic canine filarial parasites Dirofilaria (Nochtiella) repens and Candidatus Dirofilaria (Nochtiella) Honkongensis provide evidence for presence of cryptic species. PLoS Negl Trop Dis. 2016;10:e0005028.

11. Yilmaz E, Wongkamchai $\mathrm{S}$, Ramünke $\mathrm{S}$, Koutsovoulos GD, Blaxter ML, Poppert S, et al. High genetic diversity in the Dirofilaria repens species complex revealed by mitochondrial genomes of feline microfilaria samples from Narathiwat, Thailand. Transbound Emerg Dis. 2019;66:389-99.

12. Gowrishankar S, Aravind M, Sastya S, Latha BR, Azhahianambi P, Vairamuthu S, et al. Dirofilaria hongkongensis - a first report of potential zoonotic dirofilariosis infection in dogs from Tamil Nadu. Vet Parasitol Reg Stud Reports. 2019;18:100326.

13. Pradeep RK, Nimisha M, Pakideery V, Johns J, Chandy G, Nair S, et al. Whether Dirofilaria repens parasites from South India belong to zoonotic Candidatus Dirofilaria hongkongensis (Dirofilaria sp. hongkongensis)? Infect Genet Evol. 2019;67:121-5.

14. Manoj RRS, latta R, Latrofa MS, Capozzi L, Raman M, Colella V, et al. Canine vector-borne pathogens from dogs and ticks from Tamil Nadu, India. Acta Trop. 2020;203:105308.

15. Xing F, Li X, Lo SKF, Poon RWS, Lau SKP, Woo PCY. Dirofilaria hongkongensis infection presenting as recurrent shoulder mass. Parasitol Int. 2020;77:102117.
16. ICZN. International Code of Zoological Nomenclature. 4th ed. London: The International Trust for Zoological Nomenclature; 1999.

17. Otranto D, Diniz DG, Dantas-Torres F, Casiraghi M, Almeida INF, Almeida LNF, et al. Human intraocular filariasis caused by Dirofilaria sp. nematode. Brazil. Emerg Infect Dis. 2011;17:863-6.

18. Socolovschi C, Kernif T, Raoult D, Parola P. Borrelia, Rickettsia, and Ehrlichia species in bat ticks, France, 2010. Emerg Infect Dis. 2012;18:1966-75.

19. Dahmana H, Granjon L, Diagne C, Davoust B, Fenollar F, Mediannikov O. Rodents as hosts of pathogens and related zoonotic disease risk. Pathogens. 2020;9:E202.

20. Murray RG, Schleifer KH. Taxonomic notes: a proposal for recording the properties of putative taxa of procaryotes. Int J Syst Bacteriol. 1994:44:174-6.

21. Murray RG, Stackebrandt E. Taxonomic note: implementation of the provisional status Candidatus for incompletely described procaryotes. Int J Syst Bacteriol. 1995:45:186-7.

22. Parker CT, Tindall BJ, Garrity GM. International code of nomenclature of prokaryotes. Int J Syst Evol Microbiol. 2019;69:S1-111.

23. Harris DJ. Naming no names: comments on the taxonomy of small piroplasmids in canids. Parasit Vectors. 2016:9:289.

\section{Publisher's Note}

Springer Nature remains neutral with regard to jurisdictional claims in published maps and institutional affiliations.
Ready to submit your research? Choose BMC and benefit from

- fast, convenient online submission

- thorough peer review by experienced researchers in your field

- rapid publication on acceptance

- support for research data, including large and complex data types

- gold Open Access which fosters wider collaboration and increased citations

- maximum visibility for your research: over $100 \mathrm{M}$ website views per year

At BMC, research is always in progress.

Learn more biomedcentral.com/submissions 